\title{
Mahasiswa Berdedikasi Tinggi
}

J. Julia

2018 


\section{CAMBRIDGE DICTIONARY}

College Student (Mahasiswa/i):

"a group of people with a particular job, purpose, duty or power who are organized into a group for sharing ideas, making decisions, etc" 


\section{CAMBRIDGE DICTIONARY}

\section{Dedication:}

"When you give a lot of time and energy to something because it is important"

$$
\text { give time energy something important }
$$


Menyediakan

Give $\rightarrow$ Menawarkan

Mengusulkan

Menyarankan

Memberikan

$$
\text { Time } \rightarrow \quad \begin{aligned}
& \text { Pagi } \\
& \text { Siang } \\
& \text { Sore } \\
& \text { Malam }
\end{aligned}
$$

$$
\begin{array}{ll}
\text { Daya } \\
\text { Energy } \rightarrow \quad \begin{array}{l}
\text { Kekuatan } \\
\text { Tenaga } \\
\text { Gairah } \\
\text { Pikiran }
\end{array}
\end{array}
$$


Pendidikan:

- Kompetensi

- Standar Isi

- Standar Proses

Something $\rightarrow \quad-$ Standar Pendidik dan Kependidikan

- Sarana dan Prasarana

- Pengelolaan

- Pembiayaan

- Penilaian

- Atau Kontekstual
Berkedudukan

$\begin{array}{ll}\text { Important } \rightarrow \quad & \text { Krusial } \\ \text { Skala Prioritas }\end{array}$

Menentukan 


\section{TIPS MENJADI MAHASISWA BERDEDIKASI TINGGI}

\section{- Taqwa}

- Memelihara dan meningkatkan keimanan kepada Allah SWT;

- Menjaga keshalehan ritual;

- Mengembangkan keshalehan sosial;

- Menjaga dan melaksanakan akhlakul karimah;

- Someah

- Selalu bersikap ramah;

- Tulus dalam tekad, ucap dan segala perbuatan;

- Tidak berlaku diskriminatif;

- Rendah hati (handap asor);

- Murah senyum. 


\section{- Surti}

- Merasa empati dan simpati;

- Tidak suka menyakiti orang lain;

- Bijak;

- Memiliki "sense of crisis";

- Selalu berusaha mengasah mata hati (kepekaan).

\section{- Jembar}

- Berwawasan luas;

- Demokratis;

- Mudah memberi maaf dan tidak keras hati;

- Menghargai kelebihan orang lain dan mendorong orang lain untuk berkembang;

- Sabar dan tawakal. 


\section{- Brukbrak}

- Bersikap transparan;

- Jujur;

- Tidak mempersulit yang mudah;

- Menjungjung tinggi supremasi hukum;

- Tidak memendam kebencian kepada orang lain.

\section{- Guyub}

- Memegang teguh komitmen;

- Suka bekerja sama dan bergotong royong;

- Membangun sinergitas;

- Memelihara persatuan;

- Suka saling membantu. 


\section{- Motekar}

- Kreatif dan inovatif;

- Dinamis;

- Selalu memiliki gagasan segar;

- Mampu memanfaatkan sumber daya yang ada secara maksimal;

- Menguasai ilmu pengetahuan dan teknologi.

- Tarapti, Taliti, Ati-ati

- Profesional;

- Waspada, cermat dan teliti dalam mengerjakan sesuatu;

- Menempatkan sesuatu sesuai dengan tempatnya;

- Tenang dan tidak mudah terpengaruh oleh hasutan;

- Matang pertimbangannya dalam mengambil suatu keputusan. 


\section{- Junun-Jucung}

- Konsisten;

- Berorientasi pada proses bukan semata-mata pada hasil;

- Tidak cepat putus asa dan berani menghadapi tantangan;

- Mengerjakan dan melakukan sesuatu sampai tuntas, tidak setengah-setengah (totalitas);

- Hasil kerja kerasnya dapat bermanfaat bagi dirinya dan orang banyak.

\section{- Punjul-Luhung}

- Berani mengambil keputusan;

- Memiliki daya kompetensi yang tinggi;

- Berusaha melakukan dan memberikan yang terbaik;

- Memiliki rasa malu yang tinggi untuk berbuat hal yang tidak baik;

- Menjaga nilai-nilai luhur budayanya. 


\section{POTENSI HAMBATAN MENJADI MAHASISWA BERDEDIKASI TINGGI}

- Malas

- Pasif Berpikir

- Tidak Visioner

- Jauh dari Budaya Literasi

- Lemah Iman dan Lemah Mental 


\section{POTENSI TIPE MAHASISWA (ANTARA DEDIKASI DAN VARIASI)}

1. Manusia Gambar.

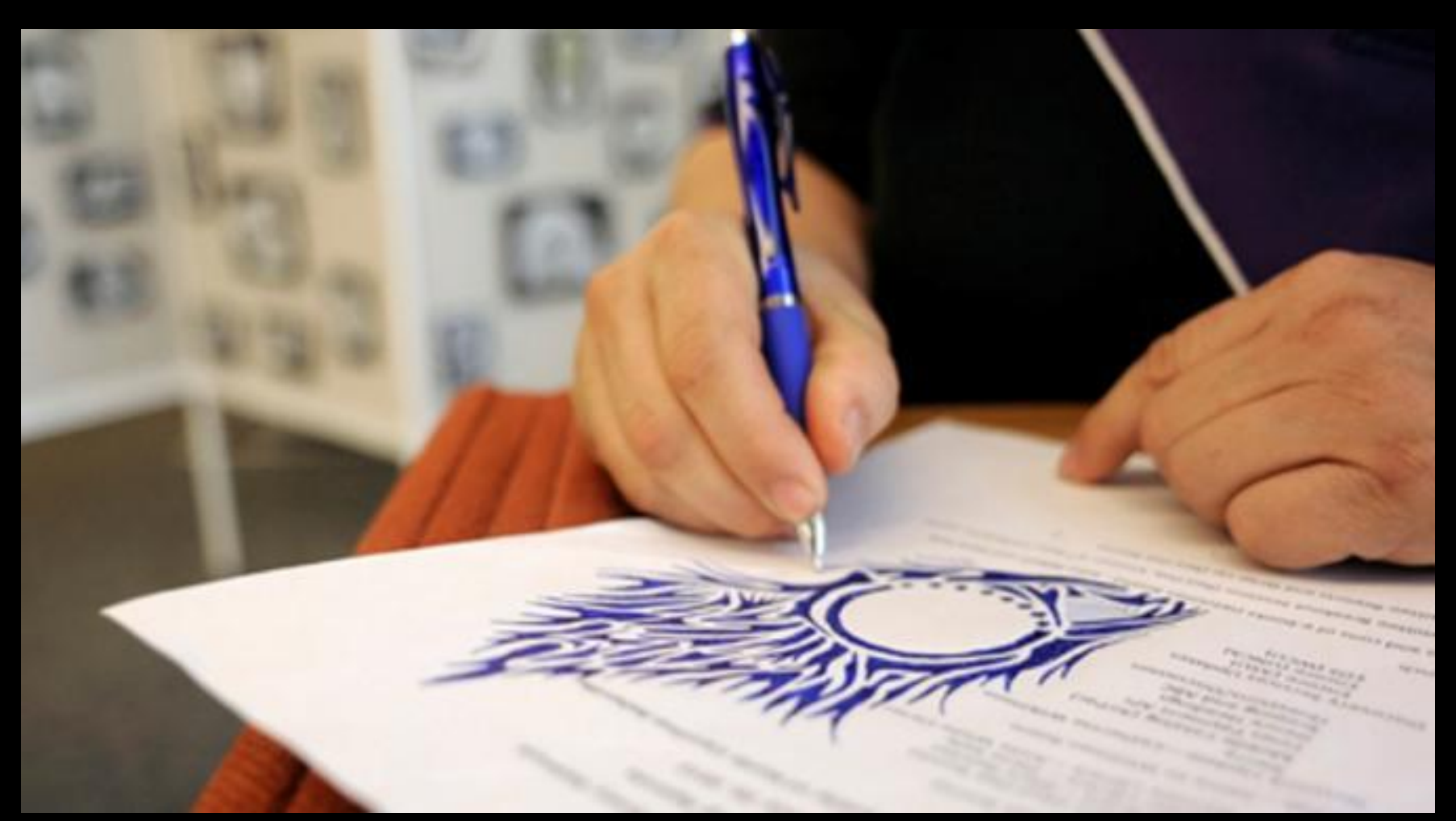




\section{Manusia Bayangan.}

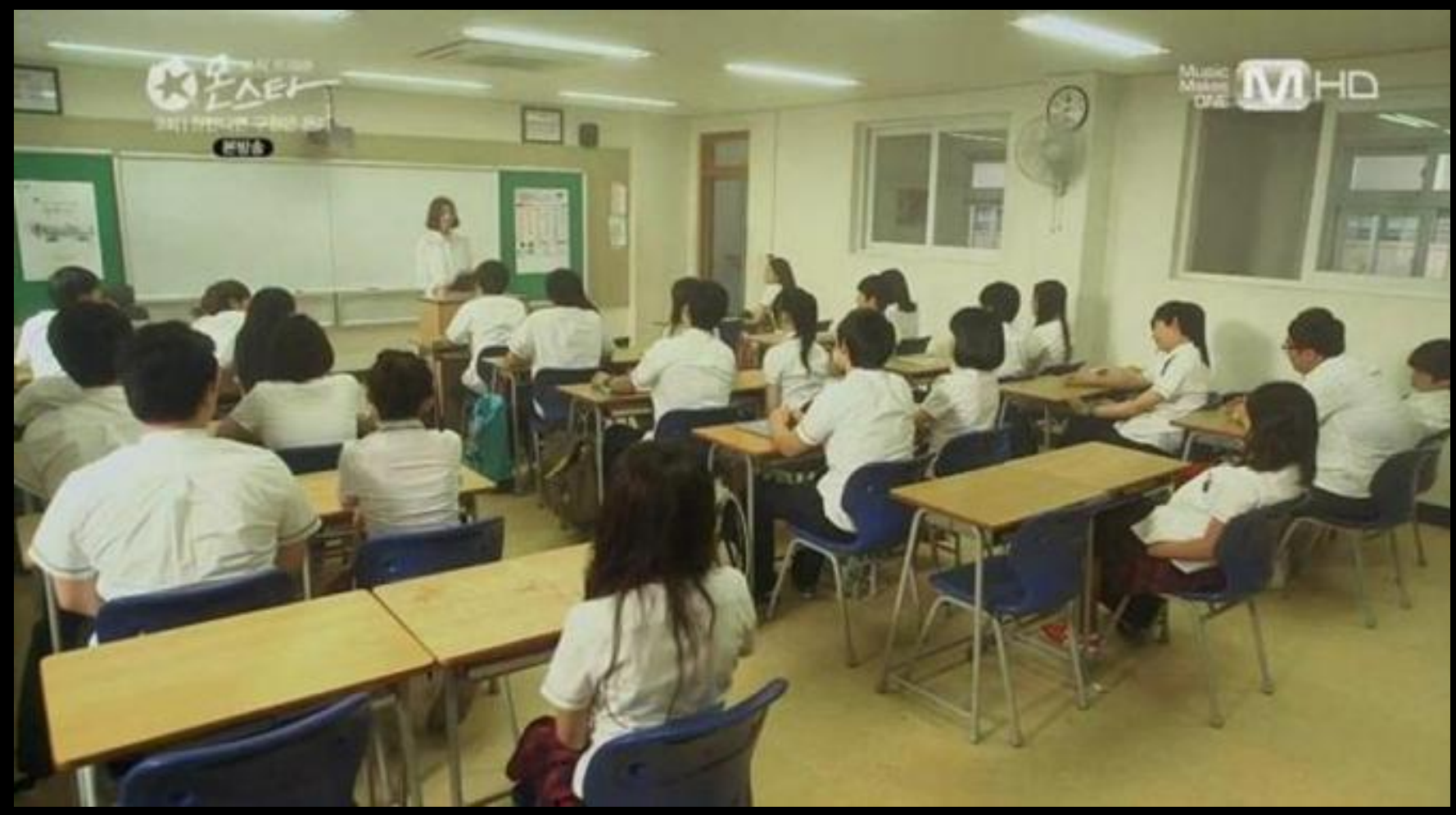


3. Manusia Toilet.

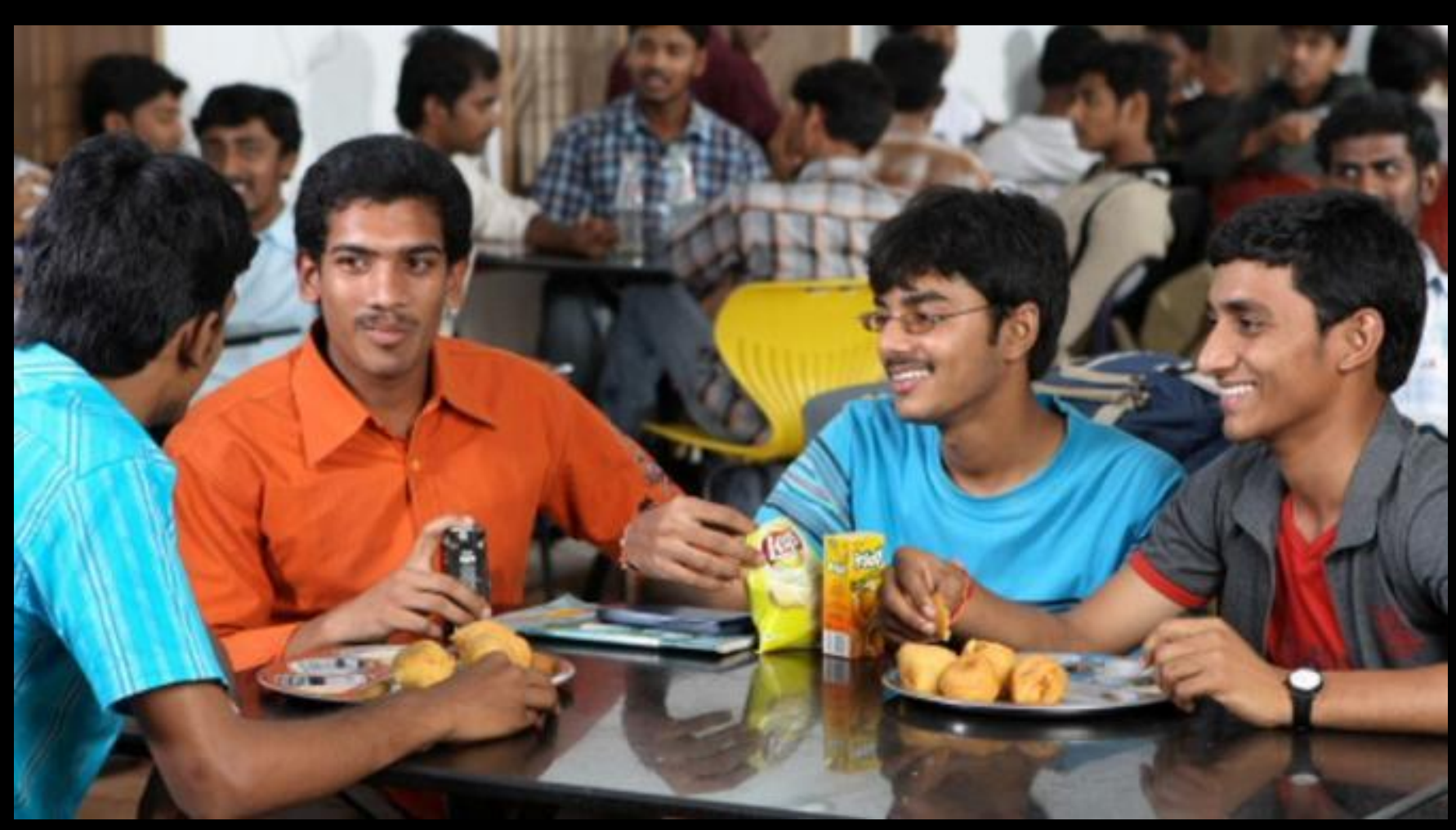


4. Manusia Titip Absen.

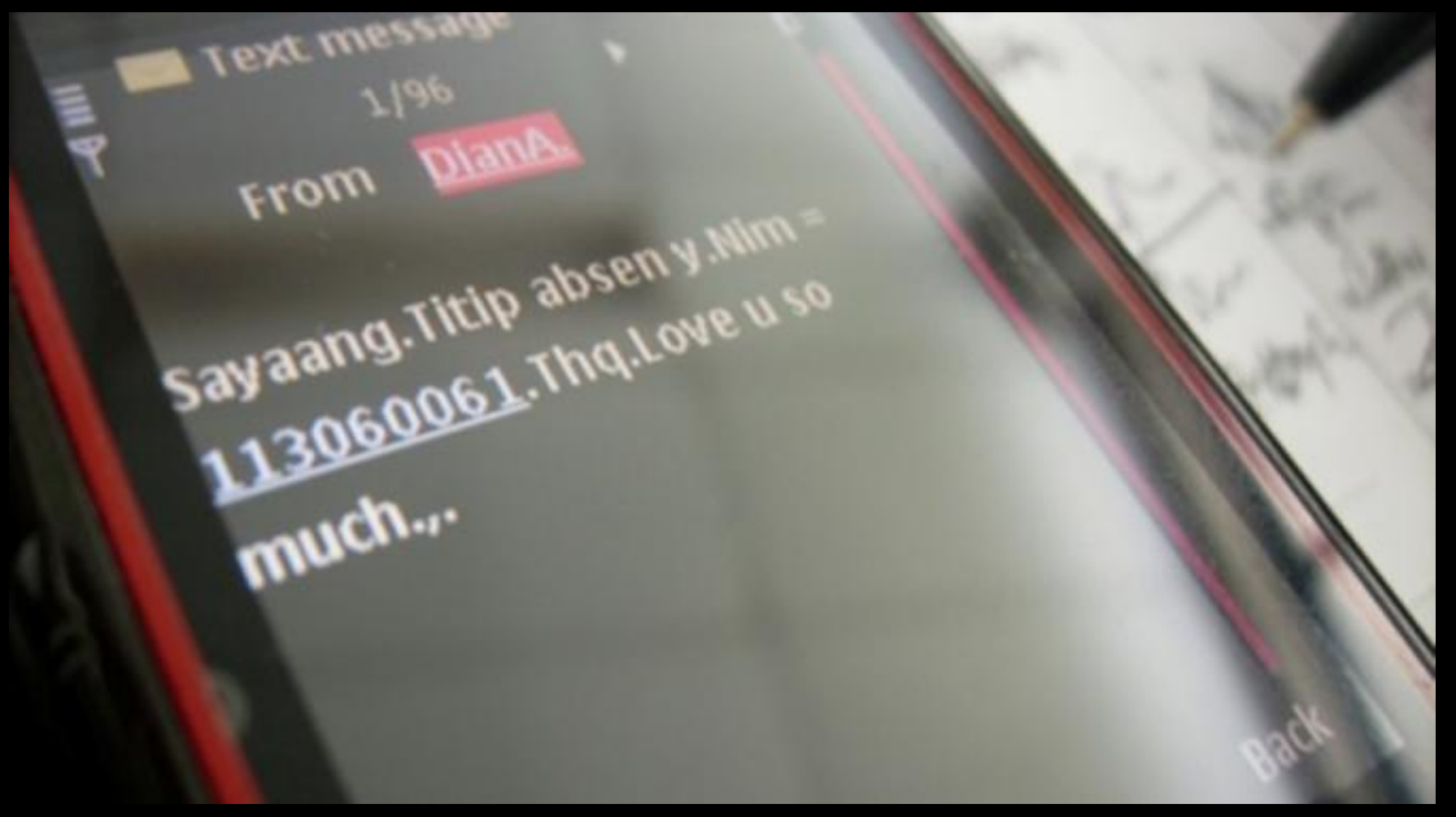


5. Manusia Separuh Dosen.

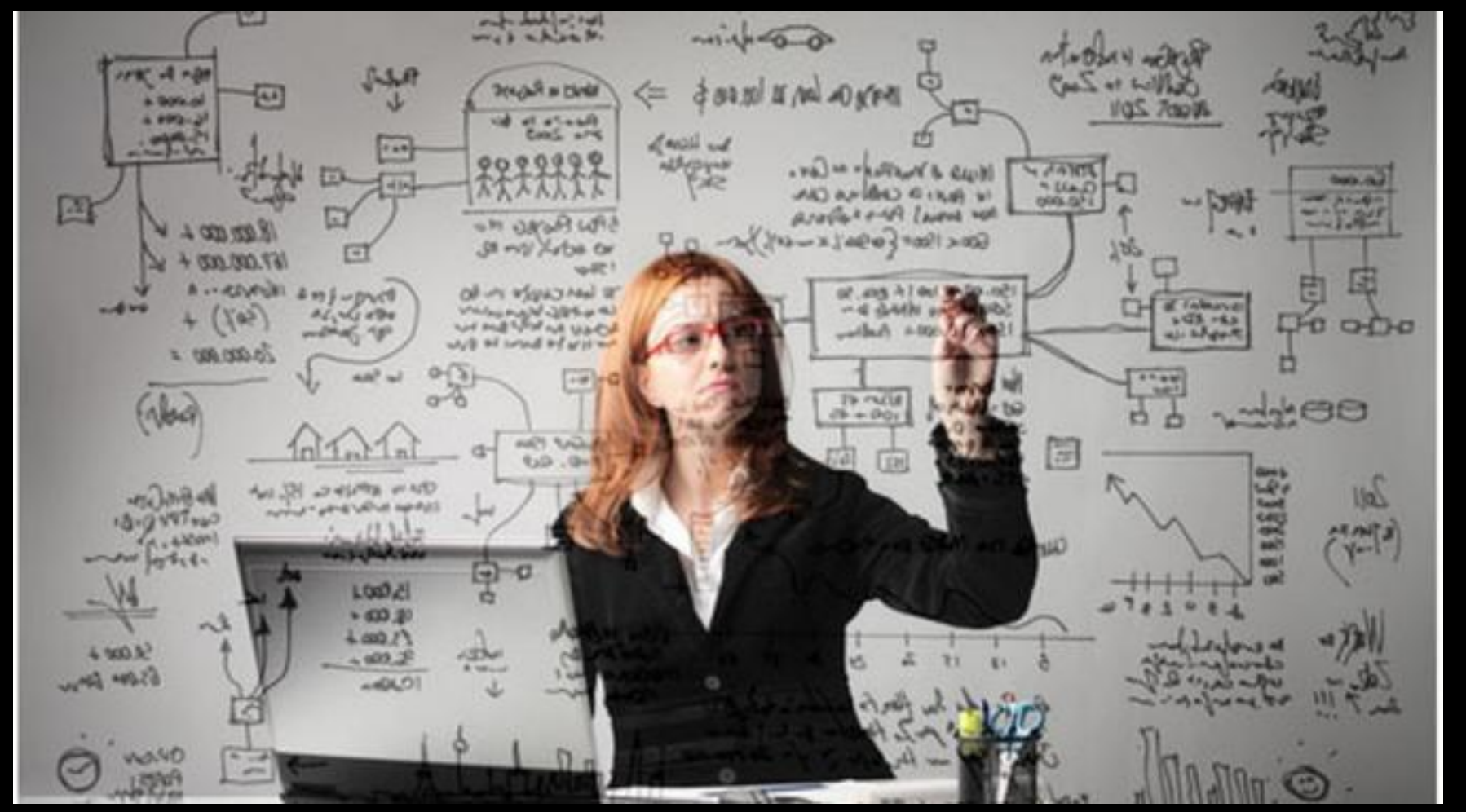


6. Manusia Tukang Minjem.

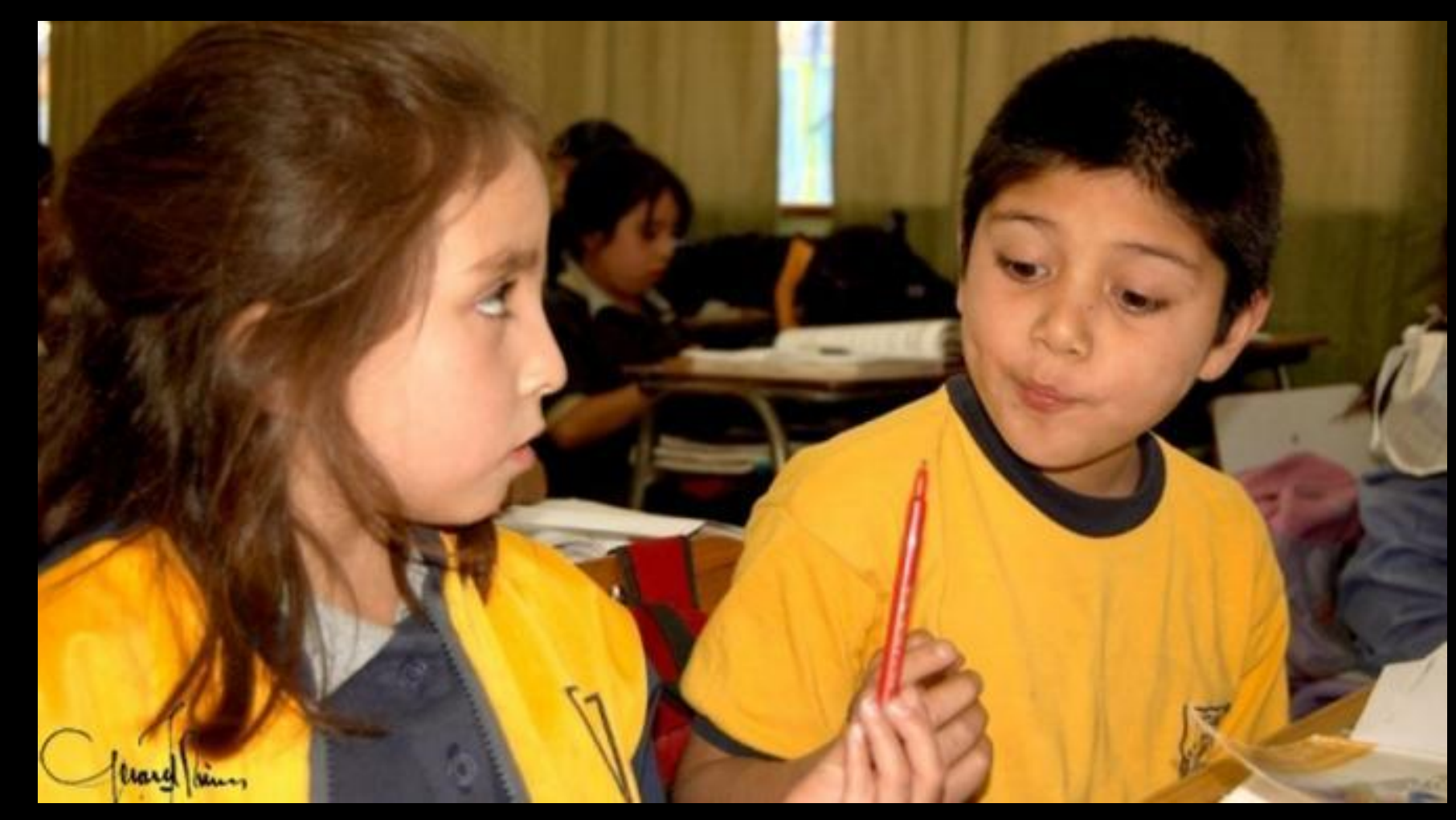


7. Manusia Tukang Makan di Kelas.

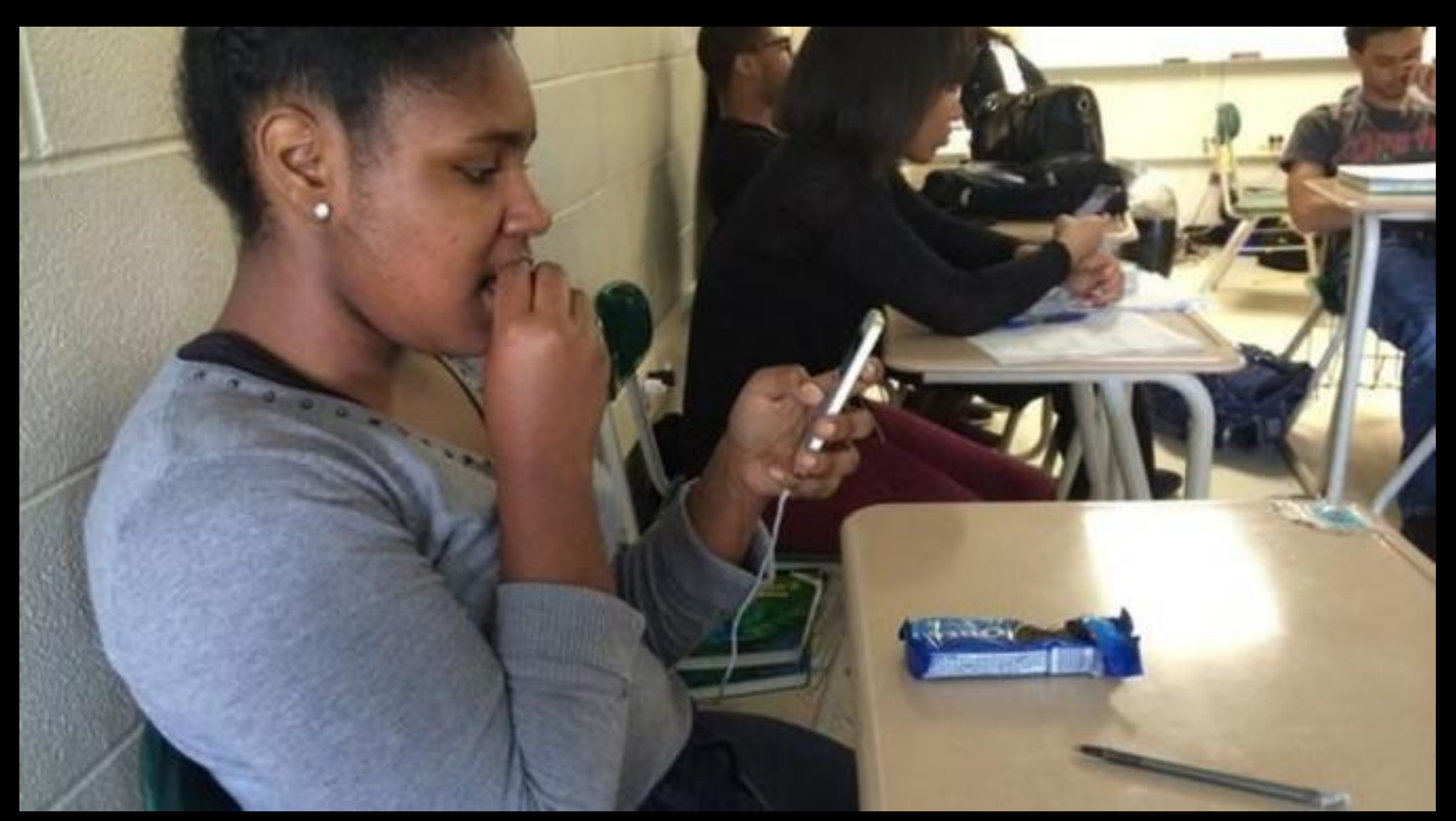


8. Manusia Tukang Tidur.

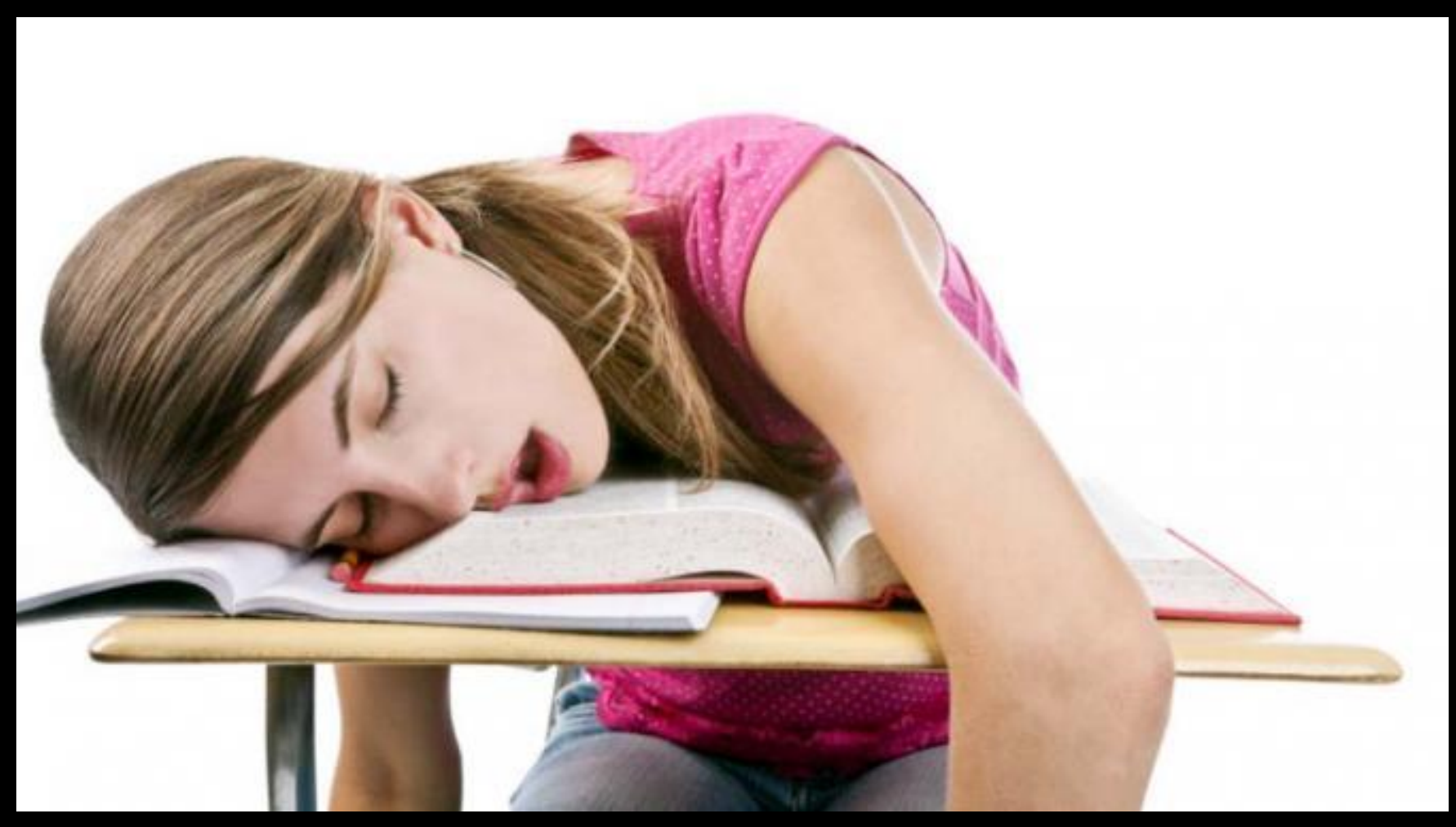


9. Manusia Freelance.

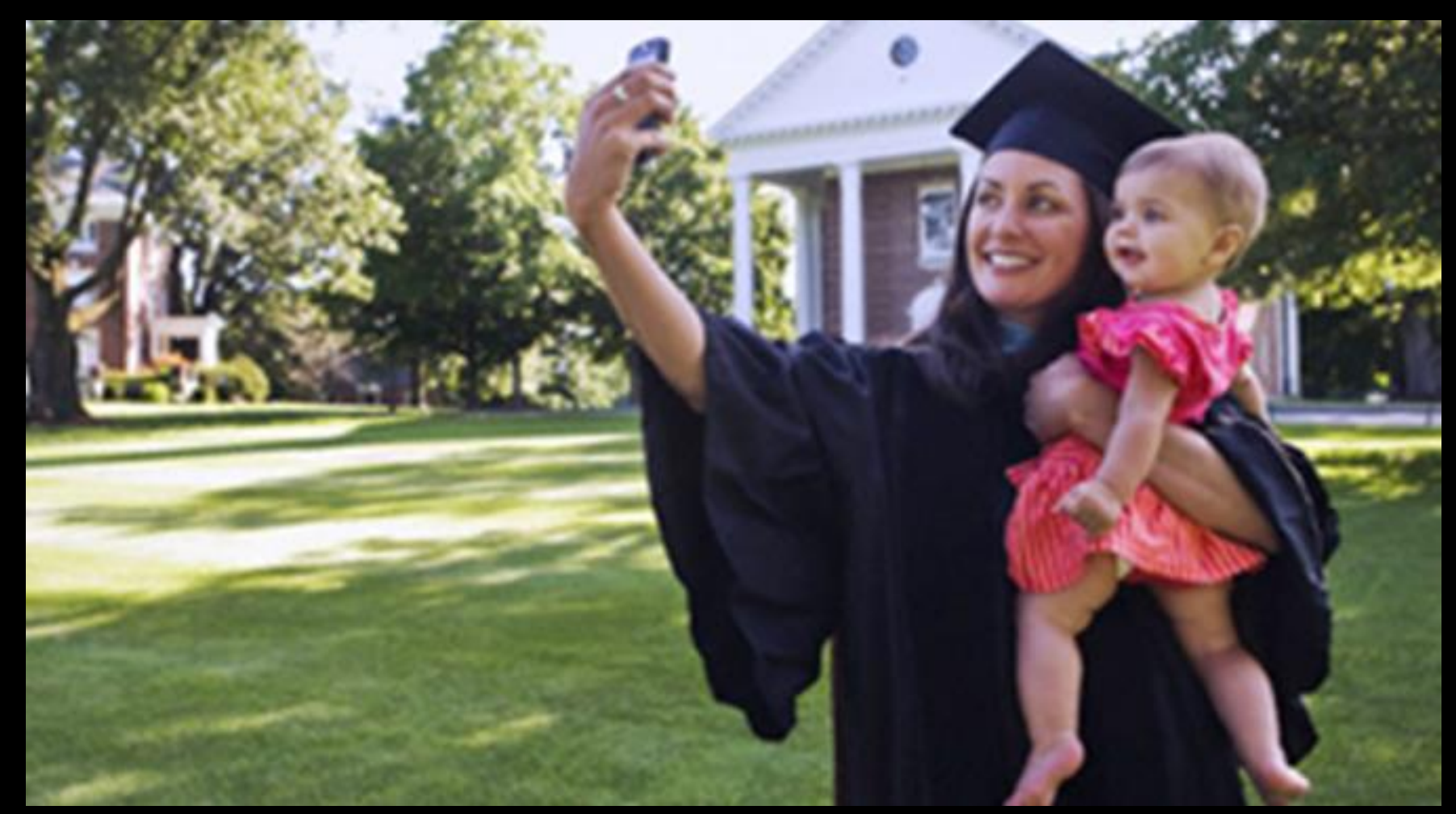


10. Manusia Aktivis Super.

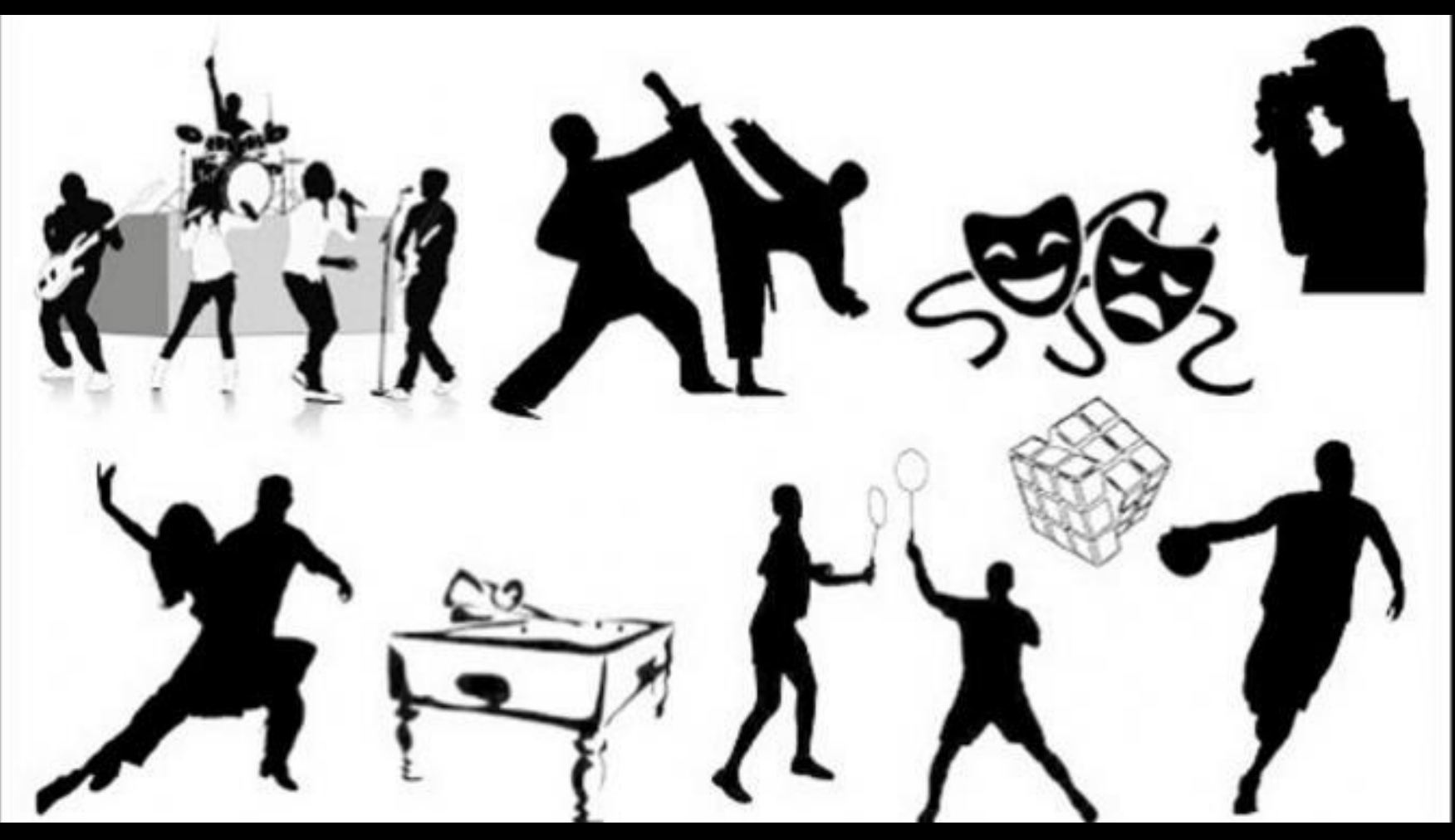


11. Manusia Kepo.

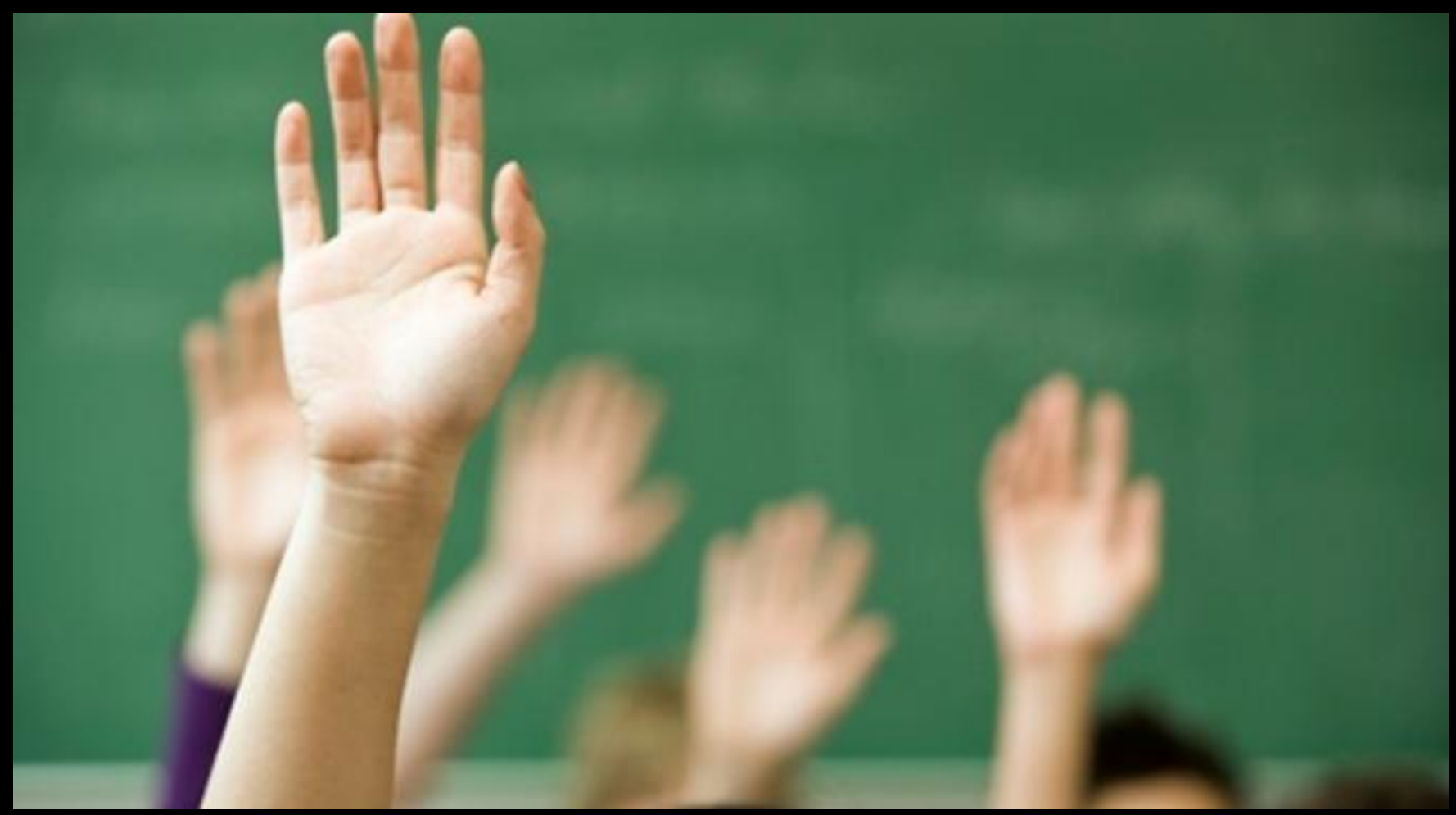


12. Manusia Si Nada Dering.

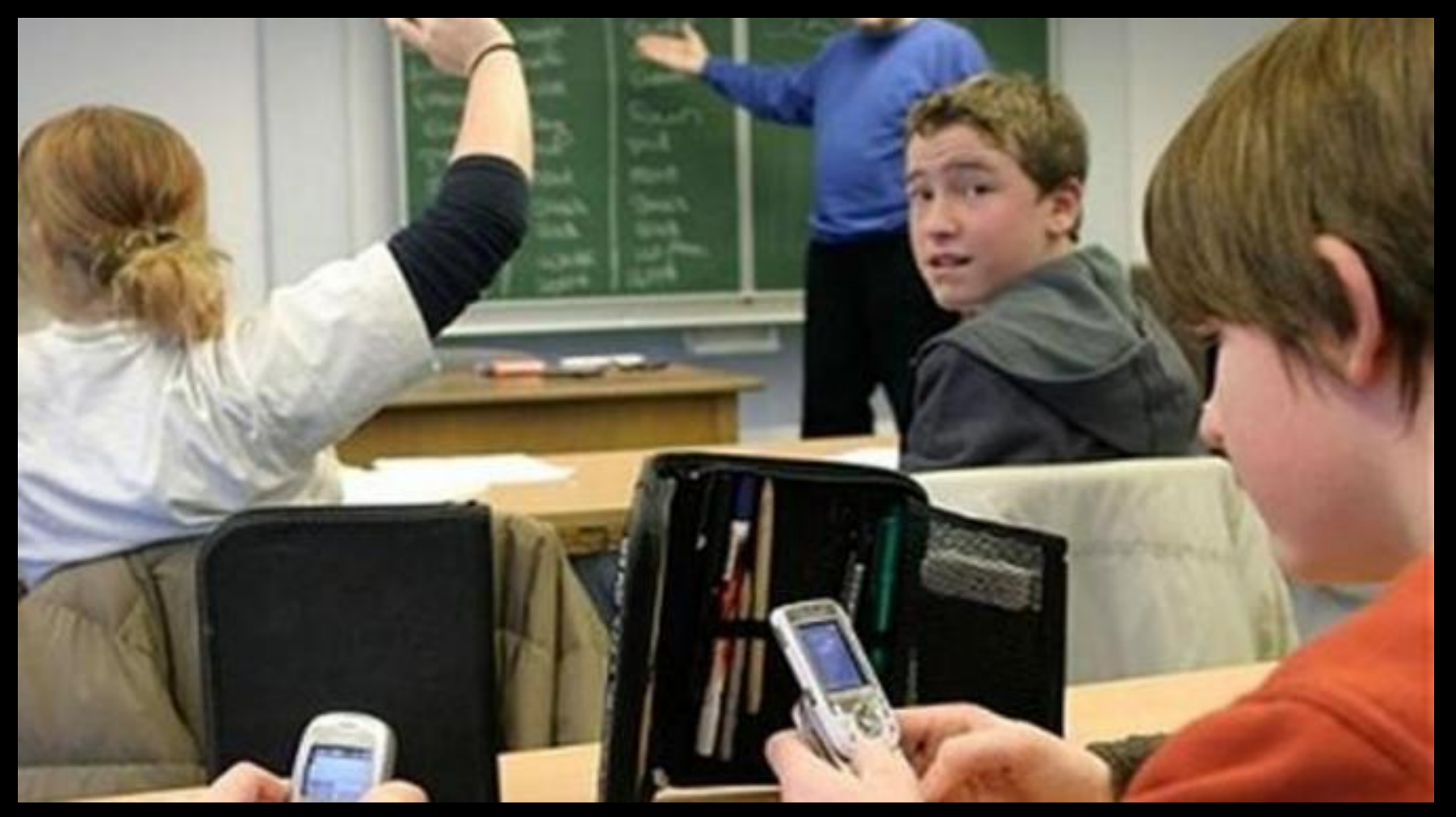


13. Manusia Gadget.

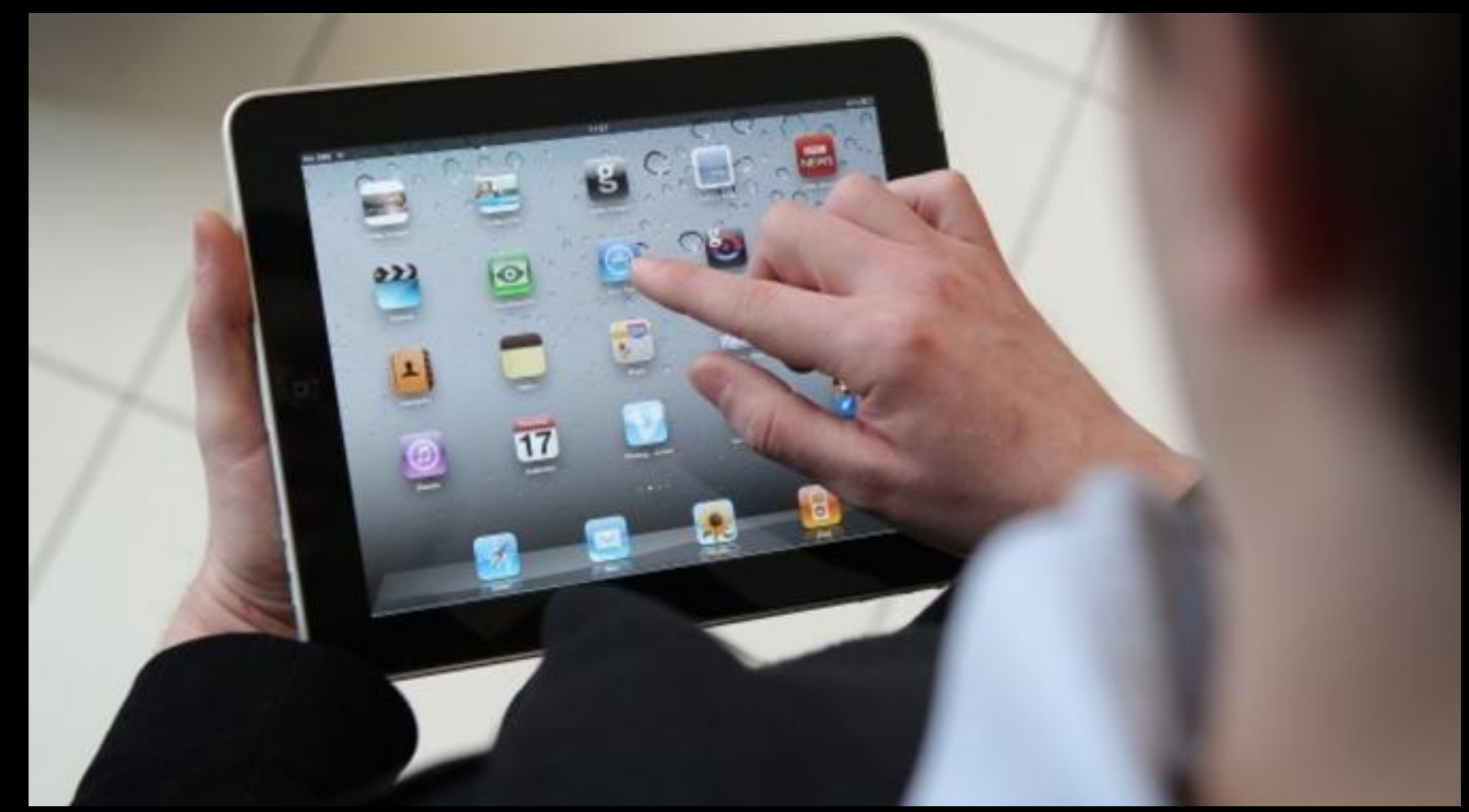




\section{TIPE HABITUASI MAHASISWA}

1. Kupu-Kupu Mati (Kuliah Pulang, Kuliah Pulang-Makan-Tidur).

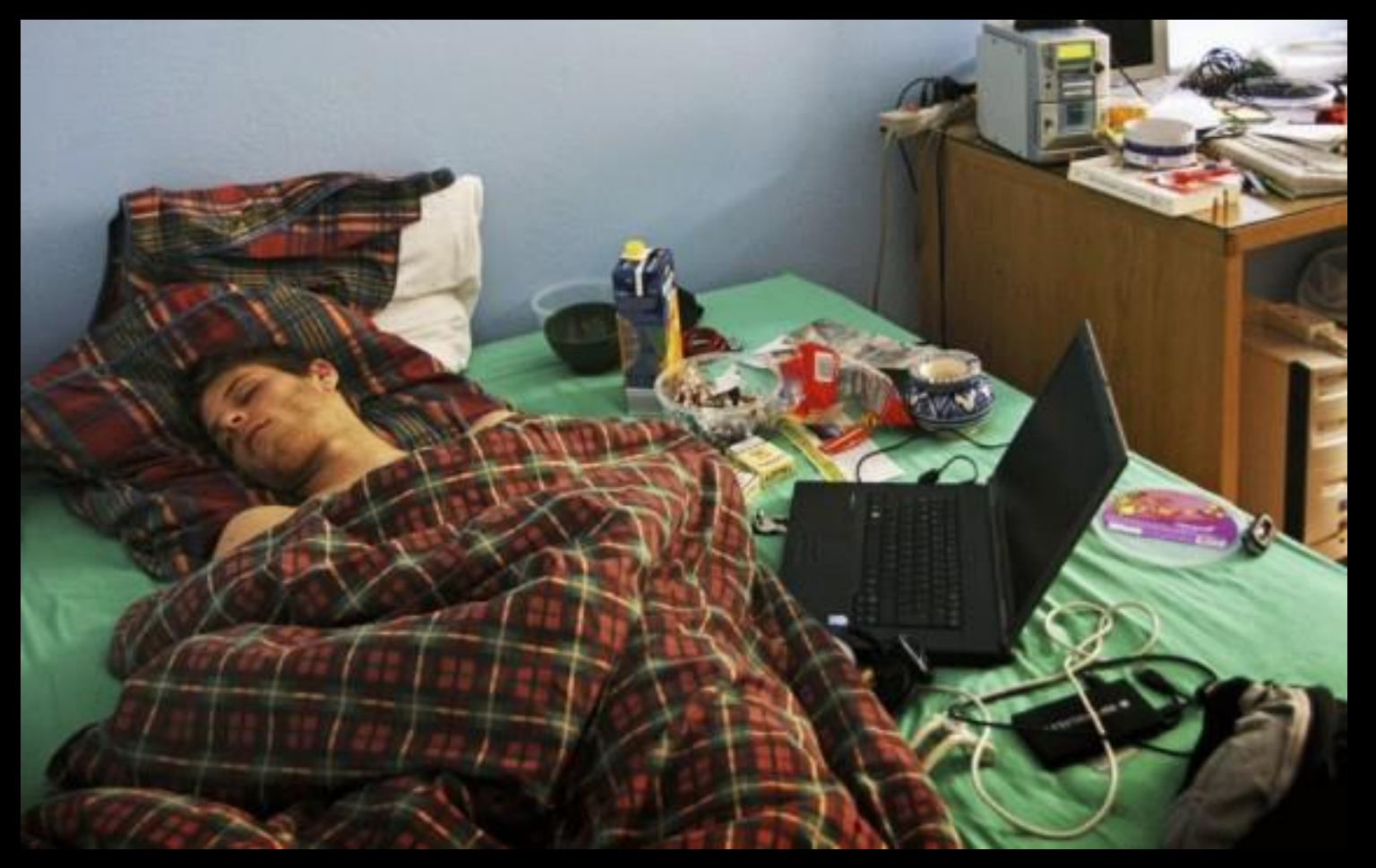


2. Kura-Kura (Kuliah Rapat, Kuliah Rapat).

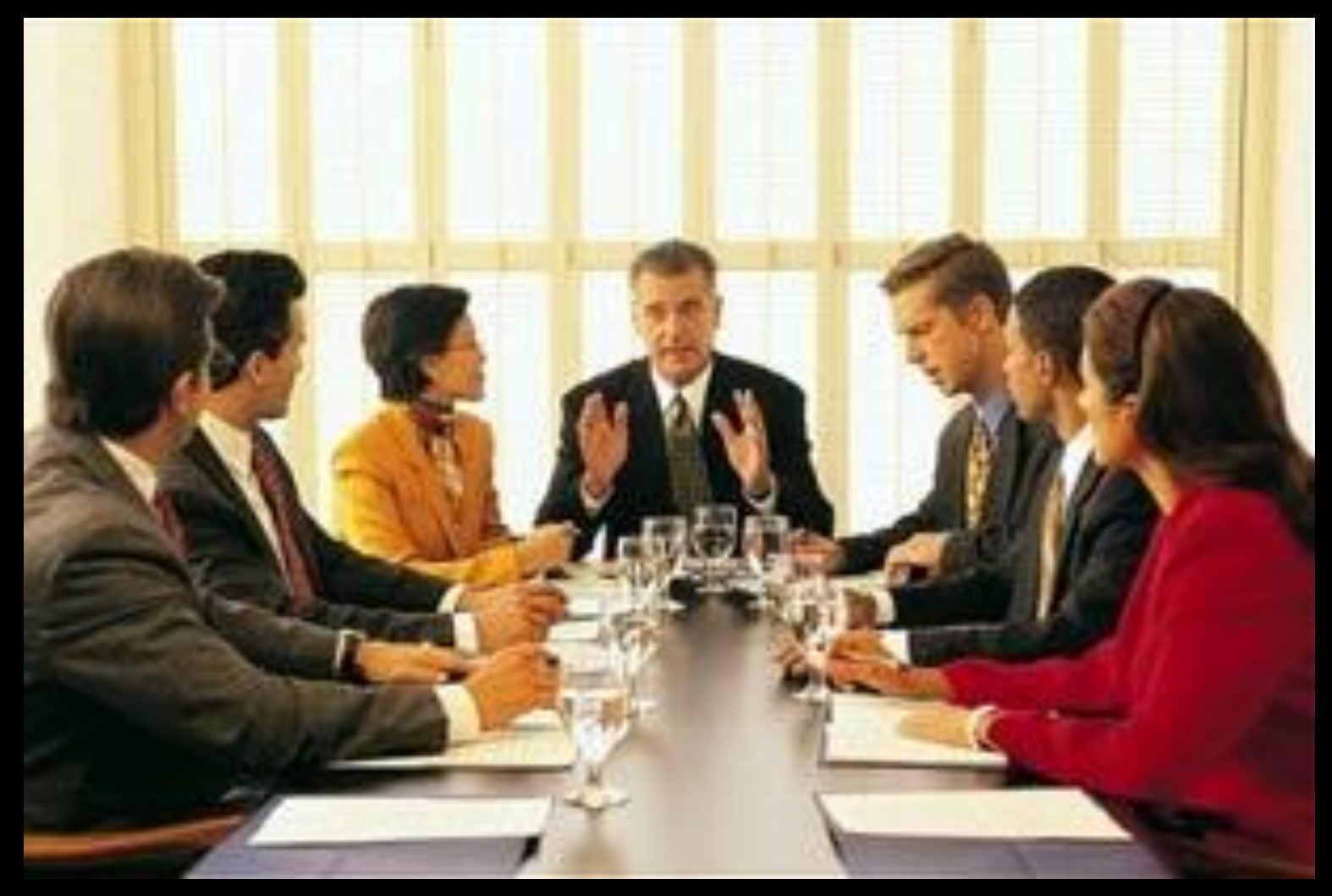


3. Kunang-Kunang (Kuliah Nangkring, Kuliah Nangkring).

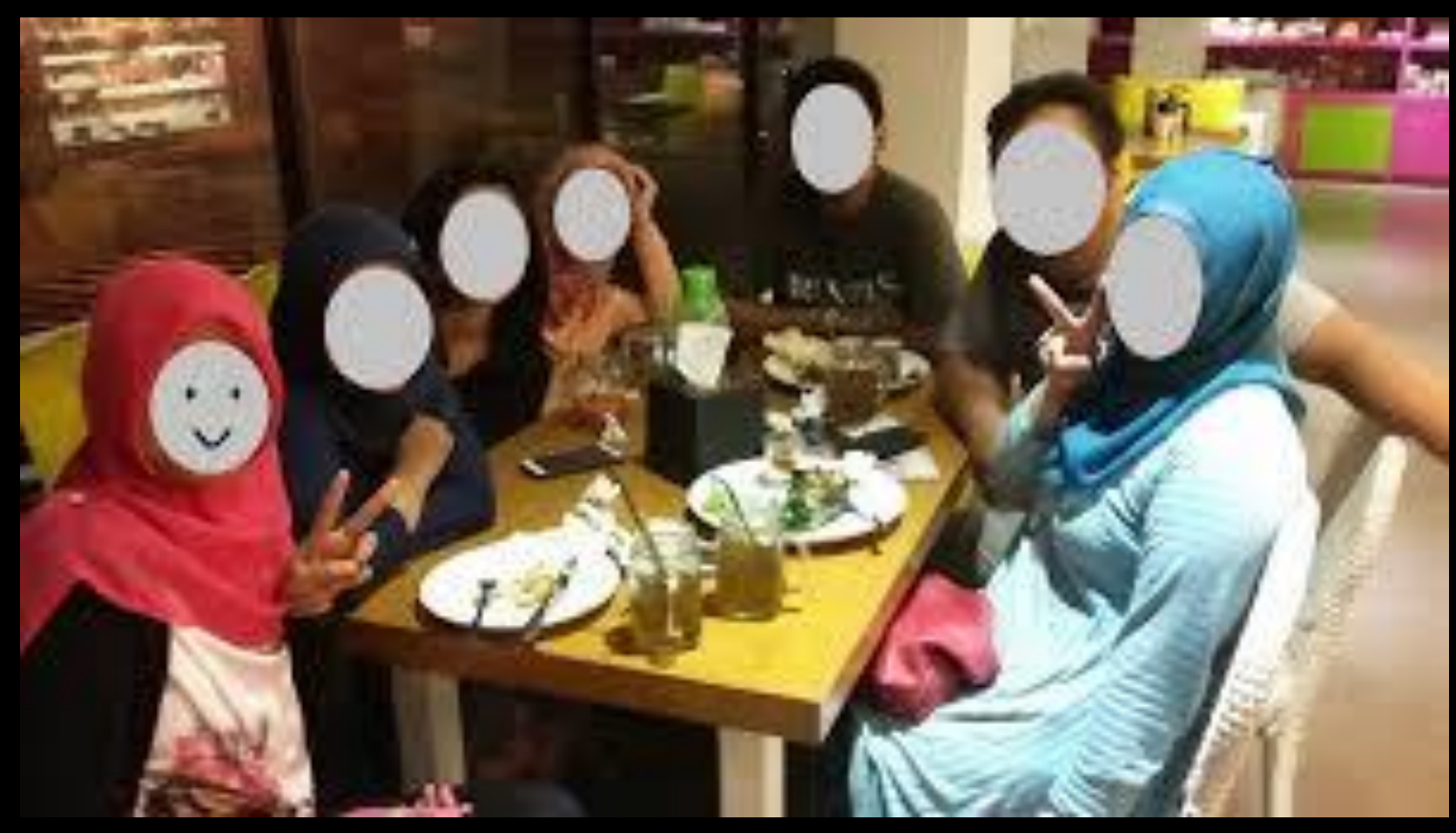


4. Kuda-Kuda (Kuliah Dagang, Kuliah Dagang).

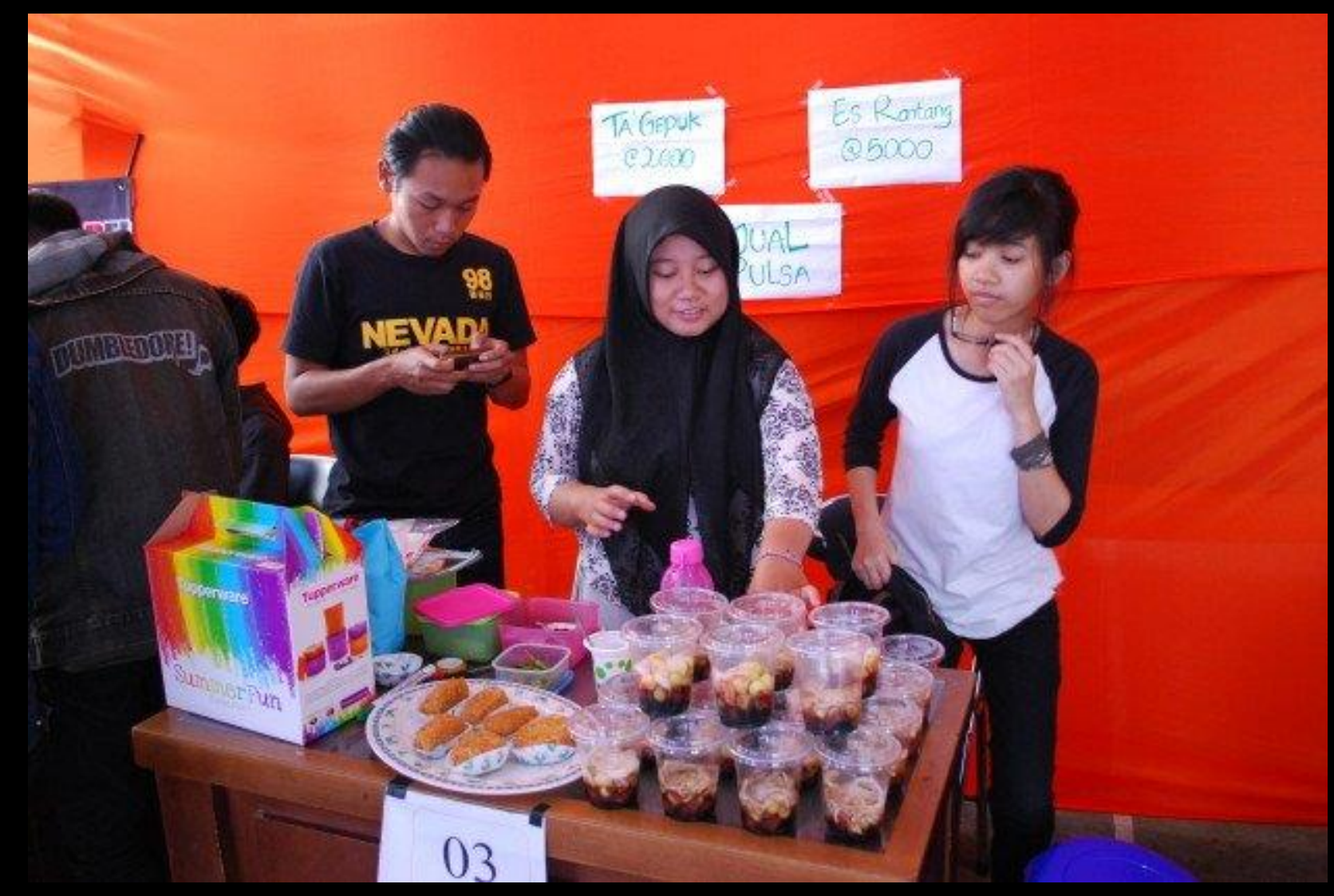




\section{PENYAKIT MAHASISWA}

1. Kurap (Kurang Rapékan)

2. Kudis (Kurang Disiplin)

3. Kadas (Kadang Kurang Cerdas) 


\section{COLLEGE PLAN}

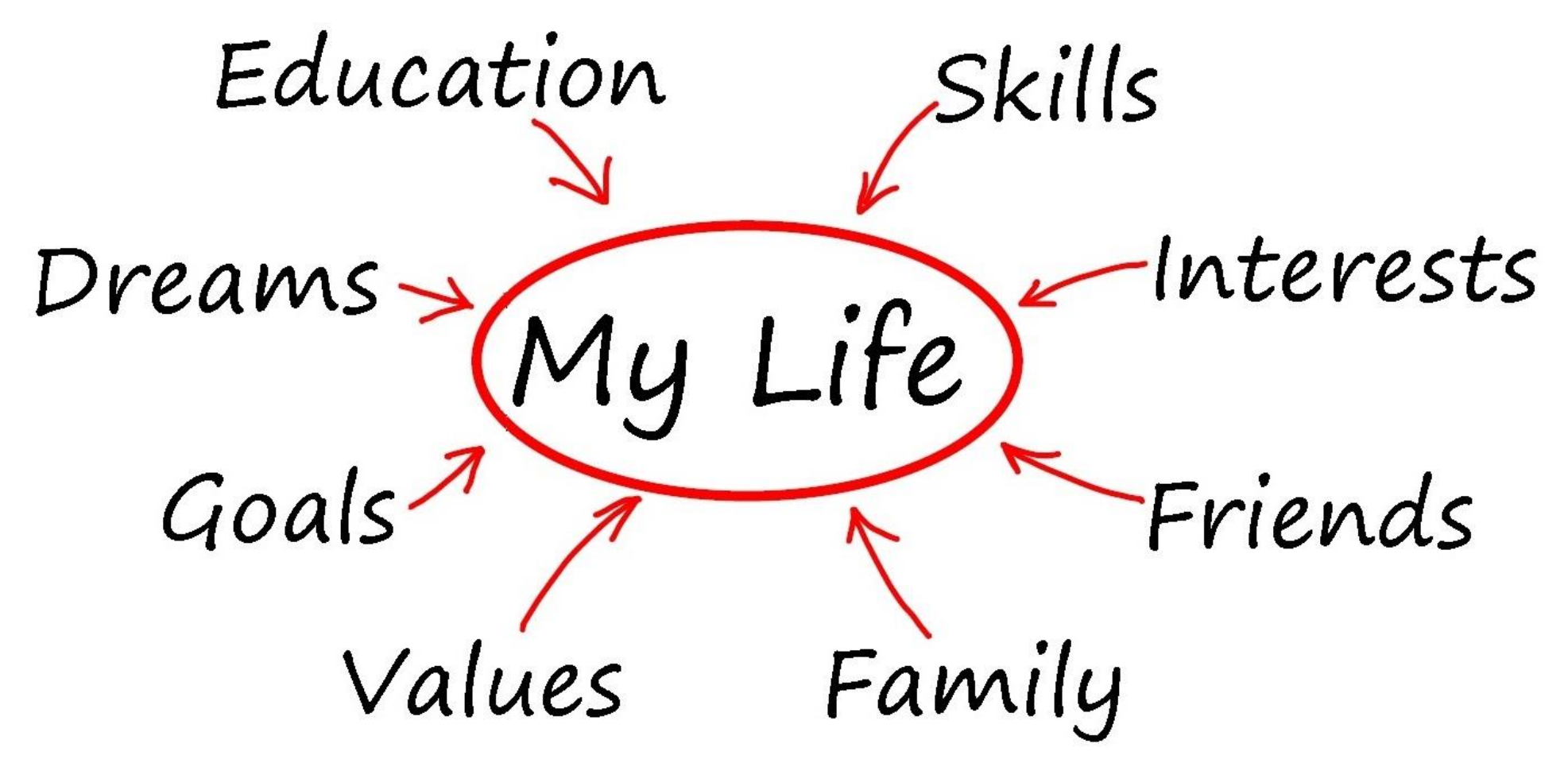




\section{My Current Plan}

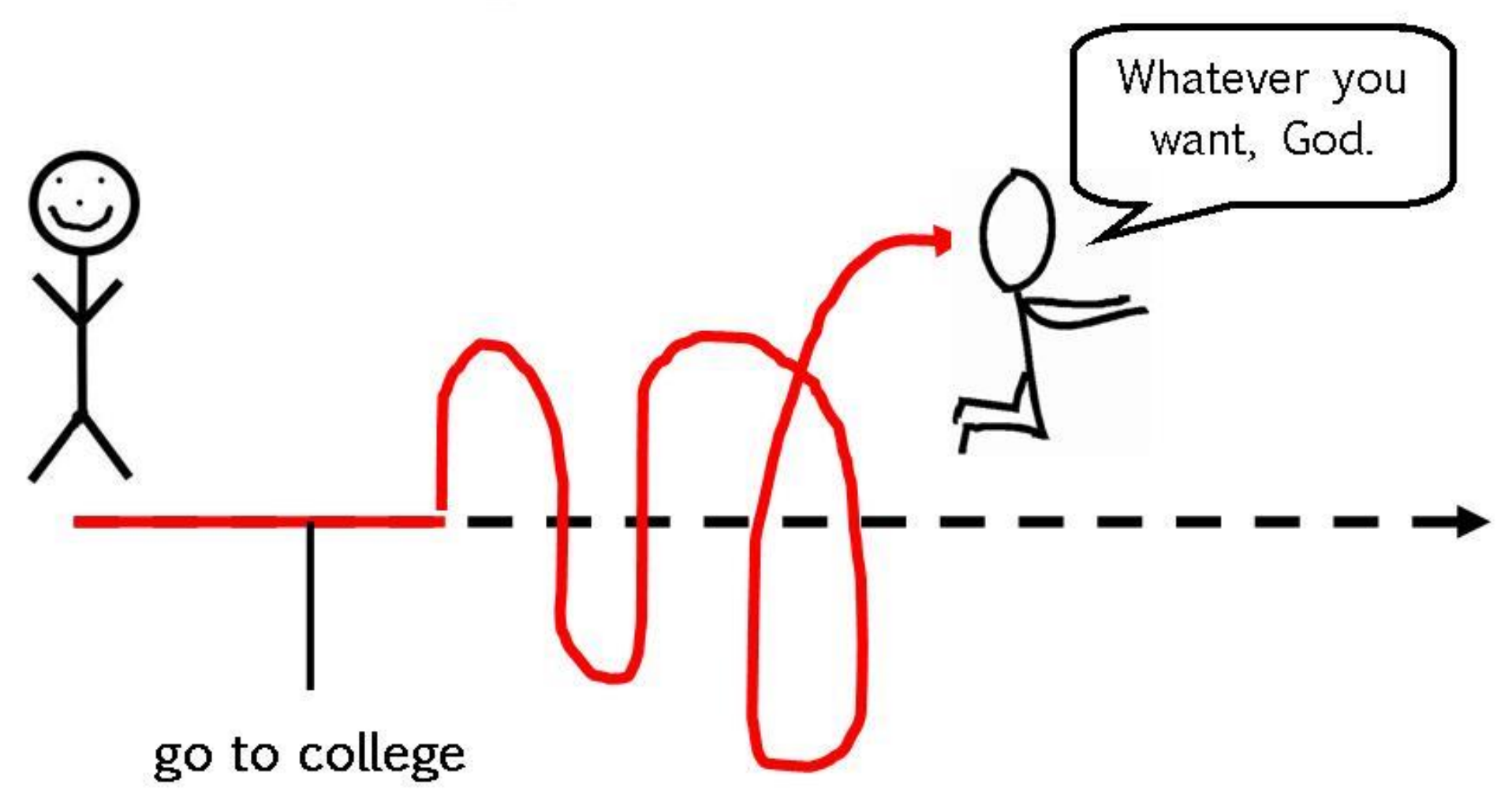




\section{SEKIAN}

Terima Kasih 


\section{REFERENSI}

- Aditya, Rizal. (2015). "13 Jenis Mahasiswa yang Ada di Kampus, Salah Satunya Pasti Kamu Banget". Tersedia: https://hype.idntimes.com/fun-fact/rizal/13-tipemahasiswa-yang-ada-di-kampus-kamu-pasti-salah-satunya/.

- Ardiansyah, Fandi. (2016). "5 Jenis Mahasiswa di Indonesia. Kamu Termasuk Nggak?" Tersedia: http://www.hipwee.com/list/5-jenis-mahasiswa-di-indonesia-kamutermasuk-nggak/

- Cambridge Advanced Learner's Dictionary Second Edition. (2005). New York: Cambridge University Press.

- Peraturan Bupati Sumedang Nomor 113 Tahun 2009 Tentang Sumedang Puseur Budaya Sunda (SPBS).

- Pratama, Yudha. (2005). "9 Jenis Mahasiswa Berdasarkan Kesibukan Mereka di Kampus! Kamu Jenis yang mana nih Guys?" Tersedia: http://papasemar.com/9jenis-mahasiswa-berdasarkan-kesibukan-mereka-di-kampus-kamu-jenis-yang-mananih-guys/ 